4

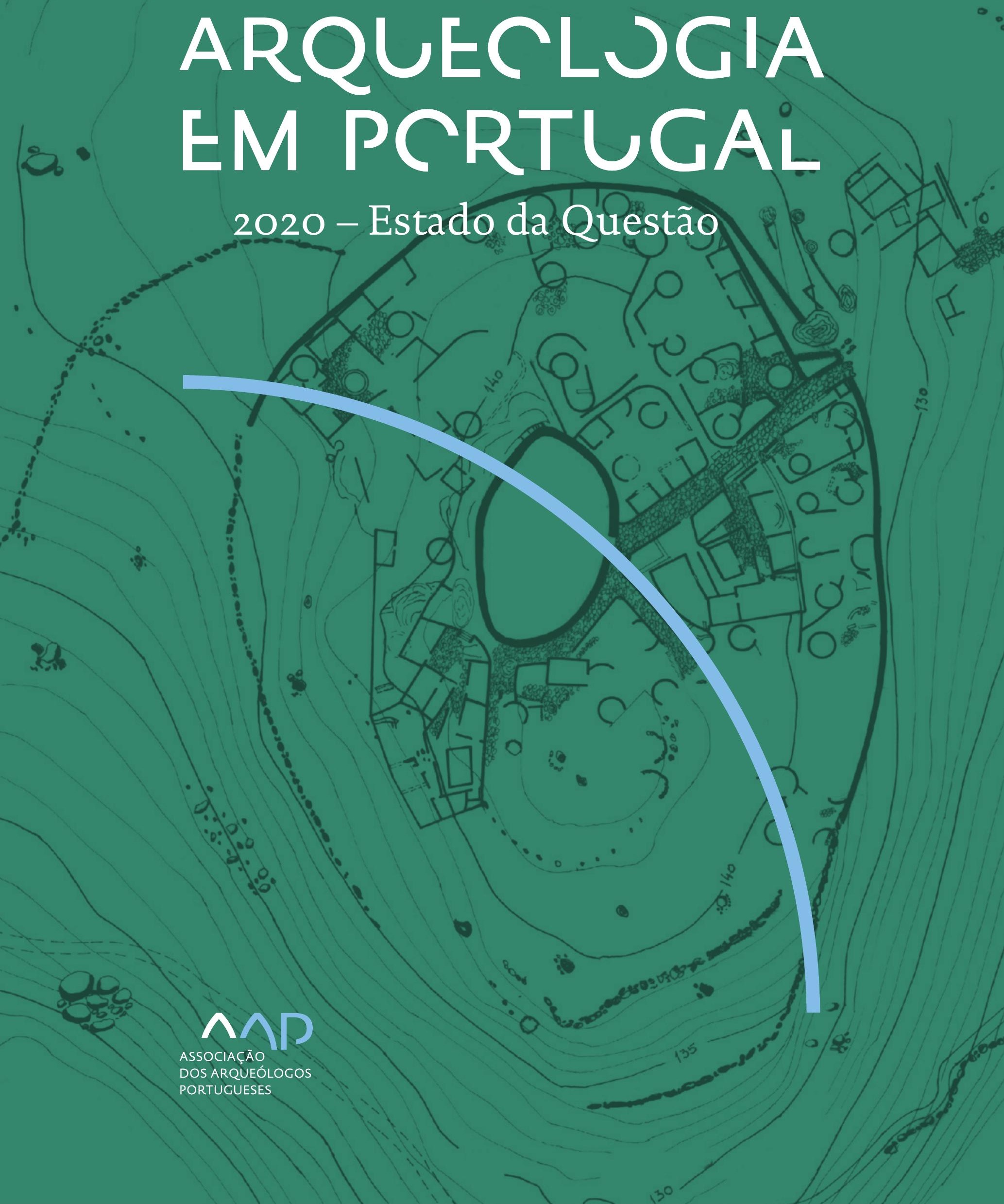


Coordenação editorial: José Morais Arnaud, César Neves e Andrea Martins Design gráfico: Flatland Design

AAP - ISBN: 978-972-9451-89-8

CITCEM - ISBN: 978-989-8970-25-1

Associação dos Arqueólogos Portugueses e CITCEM

Lisboa, 2020

O conteúdo dos artigos é da inteira responsabilidade dos autores. Sendo assim a Associação dos Arqueólogos Portugueses declina qualquer responsabilidade por eventuais equívocos ou questões de ordem ética e legal.

Desenho de capa:

Planta do castro de Monte Mozinho (Museu Municipal de Penafiel).

\section{$\hat{\wedge} \mathrm{P}$}

DOS ARQUEÓLOGOS PORTUGUESES

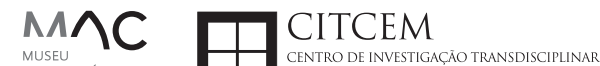
MUSEU
ARQUELLÓGICO
DO CARMO
U.PORTO

FLUP FACULDADE DE LETRAS
UNIVERSIDADE DO PORTO

Apoio

EC para a Ciência 


\section{Índice}

15 Prefácio

José Morais Arnaud

\section{Historiografia e Teoria}

17 Território, comunidade, memória e emoção: a contribuição da história da arqueologia (algumas primeiras e breves reflexões)

Ana Cristina Martins

25 Como descolonizar a arqueologia portuguesa?

Rui Gomes Coelho

41 Arqueologia e Modernidade: uma revisitação pessoal e breve de alguns aspetos da obra homónima de Julian Thomas de 2004

Vítor Oliveira Jorge

57 Dados para a História das Mulheres na Arqueologia portuguesa, dos finais do século XIX aos inícios do século XX: números, nomes e tabelas

Filipa Dimas / Mariana Diniz

73 Retractos da arqueologia portuguesa na imprensa: (in)visibilidades no feminino

Catarina Costeira / Elsa Luís

85 Arqueologia e Arqueólogos no Norte de Portugal Jacinta Bugalhão

101 Vieira Guimarães (1864-1939) e a arqueologia em Tomar: uma abordagem sobre o território e as gentes

João Amendoeira Peixoto / Ana Cristina Martins

115 Os memoráveis? A arqueologia algarvia na imprensa nacional e regional na presente centúria (2001-2019): características, visões do(s) passado(s) e a arqueologia

enquanto marca

Frederico Agosto / João Silva

129 A Evolução da Arqueologia Urbana e a Valorização Patrimonial no Barlavento Algarvio: Os casos de Portimão e Silves

Artur Mateus / Diogo Varandas / Rafael Boavida

\section{Gestão, Valorização e Salvaguarda do Património}

145 O Caderno Reivindicativo e as condições de trabalho em Arqueologia Miguel Rocha / Liliana Matias Carvalho / Regis Barbosa / Mauro Correia / Sara Simões / Jacinta Bugalhão / Sara Brito / Liliana Veríssimo Carvalho / Richard Peace / Pedro Peça / Cézer Santos

155 Os Estudos de Impacte Patrimonial como elemento para uma estratégia sustentável de minimização de impactes no âmbito de reconversões agrícolas Tiago do Pereiro

165 Salvaguarda de Património arqueológico em operações florestais: gestão e sensibilização Filipa Bragança / Gertrudes Zambujo / Sandra Lourenço / Belém Paiva / Carlos Banha / Frederico Tatá Regala / Helena Moura / Jacinta Bugalhão / João Marques / José Correia / Pedro Faria / Samuel Melro

179 Os valores do Património: uma investigação sobre os Sítios Pré-históricos de Arte Rupestre do Vale do Rio Côa e de Siega Verde José Paulo Francisco 
189 Conjugando recursos arqueológicos e naturais para potenciar as visitas ao Geoparque Litoral de Viana do Castelo (Noroeste de Portugal)

Hugo A. Sampaio / Ana M.S. Bettencourt / Susana Marinho / Ricardo Carvalhido

203 Áreas de Potencial Arqueológico na Região do Médio Tejo: Modelo Espacial Preditivo Rita Ferreira Anastácio / Ana Filipa Martins / Luiz Oosterbeek

223 Património Arqueológico e Gestão Territorial: O contributo da Arqueologia para a revisão do PDM de Avis

Ana Cristina Ribeiro

237 A coleção arqueológica do extinto Museu Municipal do Porto - Origens, Percursos e Estudos

Sónia Couto

251 Valpaços - uma nova carta arqueológica

Pedro Pereira / Maria de Fátima Casares Machado

263 Arqueologia na Cidade de Peniche

Adriano Constantino / Luís Rendeiro

273 Arqueologia Urbana: a cidade de Lagos como caso de Estudo Cátia Neto

285 Estratégias de promoção do património cultural subaquático nos Açores. O caso da ilha do Faial

José Luís Neto / José Bettencourt / Luís Borges / Pedro Parreira

297 Carta Arqueológica da Cidade Velha: Uma primeira abordagem

Jaylson Monteiro / Nireide Tavares / Sara da Veiga / Claudino Ramos / Edson Brito /

Carlos Carvalho / Francisco Moreira / Adalberto Tavares

311 Antropologia Virtual: novas metodologias para a análise morfológica e funcional Ricardo Miguel Godinho / Célia Gonçalves

\section{Didáctica da Arqueologia}

327 Como os projetos de Arqueologia podem contribuir para uma comunidade culturalmente mais consciente Alexandra Figueiredo / Claúdio Monteiro / Adolfo Silveira / Ricardo Lopes

337 Educação Patrimonial - Um cidadão esclarecido é um cidadão ativo! Ana Paula Almeida

351 A aproximação da Arqueologia à sala de aula: um caso de estudo no $3^{\circ}$ ciclo do Ensino Básico Luís Serrão Gil

363 Arqueologia 3.o - Pensar e comunicar a Arqueologia para um futuro sustentável Mónica Rolo

377 “Conversa de Arqueólogos" - Divulgar a Arqueologia em tempos de Pandemia Diogo Teixeira Dias

389 Escola Profissional de Arqueologia: desafios e oportunidades Susana Nunes / Dulcineia Pinto / Júlia Silva / Ana Mascarenhas

399 Os Museus de Arqueologia e os Jovens: a oferta educativa para o público adolescente Beatriz Correia Barata / Leonor Medeiros

411 O museu universitário como mediador entre a ciência e a sociedade: o exemplo da secção de arqueologia no Museu de História Natural e da Ciência da Universidade do Porto (MHNC-UP)

Rita Gaspar 
421 Museu de Lanifícios: Real Fábrica de Panos. Atividades no âmbito da Arqueologia Beatriz Correia Barata / Rita Salvado

427 Arqueologia Pública e o caso da localidade da Mata (Torres Novas) Cláudia Manso / Ana Rita Ferreira / Cristiana Ferreira / Vanessa Cardoso Antunes

431 Do sítio arqueológico ao museu: um percurso (também) didático Lídia Fernandes

447 Estão todos convidados para a Festa! E para dançar também... O projecto do Serviço Educativo do Museu Arqueológico do Carmo na $5^{\underline{a}}$ Edição da Festa da Arqueologia Rita Pires dos Santos

459 O “Clã de Carenque”, um projeto didático de arqueologia Eduardo Gonzalez Rocha

469 Mediação cultural: peixe que puxa carroça nas Ruínas Romanas de Troia Inês Vaz Pinto / Ana Patrícia Magalhães / Patrícia Brum / Filipa Santos

481 Didática Arqueológica, experiências do Projeto Mértola Vila Museu Maria de Fátima Palma / Clara Rodrigues / Susana Gómez / Lígia Rafael

\section{Arte Rupestre}

497 Os inventários de arte rupestre em Portugal Mila Simões de Abreu

513 O projeto FIRST-ART - conservação, documentação e gestão das primeiras manifestações de arte rupestre no Sudoeste da Península Ibérica: as grutas do Escoural e Maltravieso Sara Garcês / Hipólito Collado / José Julio García Arranz / Luiz Oosterbeek / António Carlos Silva / Pierluigi Rosina / Hugo Gomes / Anabela Borralheiro Pereira / George Nash / Esmeralda Gomes / Nelson Almeida / Carlos Carpetudo

523 Trabalhos de documentação de arte paleolítica realizados no âmbito do projeto PalæoCôa André Tomás Santos / António Fernando Barbosa / Luís Luís / Marcelo Silvestre / Thierry Aubry

537 Imagens fantasmagóricas, silhuetas elusivas: as figuras humanas na arte do Paleolítico Superior da região do Côa Mário Reis

$55^{1}$ Os motivos zoomórficos representados nas placas de tear de Vila Nova de São Pedro (Azambuja, Portugal) Andrea Martins / César Neves / José M. Arnaud / Mariana Diniz

571 Arte Rupestre do Monte de Góios (Lanhelas, Caminha). Síntese dos resultados dos trabalhos efectuados em 2007-2009 Mário Varela Gomes

599 Gravuras rupestres de barquiformes no Monte de S. Romão, Guimarães, Noroeste de Portugal Daniela Cardoso

613 Círculos segmentados gravados na Bacia do Rio Lima (Noroeste de Portugal): contributos para o seu estudo Diogo Marinho / Ana M.S. Bettencourt / Hugo Aluai Sampaio

631 Equídeos gravados no curso inferior do Rio Mouro, Monção (NW Portugal). Análise preliminar Coutinho, L.M. / Bettencourt, A.M.S / Sampaio, Hugo A.S

645 Paletas na Arte Rupestre do Noroeste de Portugal. Inventário preliminar Bruna Sousa Afonso / Ana M. S. Bettencourt / Hugo A. Sampaio 


\section{Pré-História}

661 O projeto Miño/Minho: balanço de quatro anos de trabalhos arqueológicos Sérgio Monteiro-Rodrigues / João Pedro Cunha-Ribeiro / Eduardo Méndez-Quintas / Carlos Ferreira / Pedro Xavier / José Meireles / Alberto Gomes / Manuel Santonja / Alfredo Pérez-González

677 A ocupação paleolítica da margem esquerda do Baixo Minho: a indústria lítica do sítio de Pedreiras 2 (Monção, Portugal) e a sua integração no contexto regional Carlos Ferreira / João Pedro Cunha-Ribeiro / Sérgio Monteiro-Rodrigues / Eduardo Méndez-Quintas / Pedro Xavier / José Meireles / Alberto Gomes / Manuel Santonja / Alfredo Pérez-González

693 O sítio acheulense do Plistocénico médio da Gruta da Aroeira Joan Daura / Montserrat Sanz / Filipa Rodrigues / Pedro Souto / João Zilhão

703 As sociedades neandertais no Barlavento algarvio: modelos preditivos com recurso aos SIG

Daniela Maio

715 A utilização de quartzo durante o Paleolítico Superior no território dos vales dos rios Vouga e Côa

Cristina Gameiro / Thierry Aubry / Bárbara Costa / Sérgio Gomes / Luís Luís / Carmen Manzano / André Tomás Santos

733 Uma perspetiva diacrónica da ocupação do concheiro do Cabeço da Amoreira (Muge, Portugal) a partir da tecnologia lítica Joana Belmiro / João Cascalheira / Célia Gonçalves

745 Novos dados sobre a Pré-história Antiga no concelho de Palmela. A intervenção arqueológica no sítio do Poceirão I

Michelle Teixeira Santos

757 Problemas em torno de Datas Absolutas Pré-Históricas no Norte do Alentejo Jorge de Oliveira

771 Povoamento pré-histórico nas áreas montanhosas do NO de Portugal: o Abrigo 1 de Vale de Cerdeira Pedro Xavier / José Meireles / Carlos Alves

783 Apreciação do povoamento do Neolítico Inicial na Baixa Bacia do Douro. A Lavra I (Serra da Aboboreira) como caso de estudo Maria de Jesus Sanches

797 O Processo de Neolitização na Plataforma do Mondego: os dados do Sector C do Outeiro dos Castelos de Beijós (Carregal do Sal)

João Carlos de Senna-Martinez / José Manuel Quintã Ventura / Andreia Carvalho / Cíntia Maurício

823 Novos trabalhos na Lapa da Bugalheira (Almonda, Torres Novas) Filipa Rodrigues / Pedro Souto / Artur Ferreira / Alexandre Varanda / Luís Gomes / Helena Gomes / João Zilhão

837 A pedra polida e afeiçoada do sítio do Neolítico médio da Moita do Ourives (Benavente, Portugal)

César Neves

857 Casal do Outeiro (Encarnação, Mafra): novos contributos para o conhecimento do povoamento do Neolítico final na Península de Lisboa.

Cátia Delicado / Carlos Maneira e Costa / Marta Miranda / Ana Catarina Sousa

873 Stresse infantil, morbilidade e mortalidade no sítio arqueológico do Neolítico Final/ Calcolítico ( $4^{\circ}$ e $3^{\circ}$ milénio a.C.) do Monte do Carrascal 2 (Ferreira do Alentejo, Beja) Liliana Matias de Carvalho / Sofia N. Wasterlain 
885 Come together: O Conjunto Megalítico das Motas (Monção, Viana do Castelo) e as expressões Campaniformes do Alto Minho Ana Catarina Basílio / Rui Ramos

899 Trabalhos arqueológicos no sítio Calcolítico da Pedreira do Poio Carla Magalhães / João Muralha / Mário Reis / António Batarda Fernandes

913 O sítio arqueológico de Castanheiro do Vento. Da arquitectura do sítio à arquitectura de um território João Muralha Cardoso

925 Estudo zooarqueológico das faunas do Calcolítico final de Vila Nova de São Pedro (Azambuja, Portugal): Campanhas de 2017 e 2018 Cleia Detry / Ana Catarina Francisco / Mariana Diniz / Andrea Martins / César Neves / José Morais Arnaud

943 As faunas depositadas no Museu Arqueológico do Carmo provenientes de Vila Nova de São Pedro (Azambuja): as campanhas de 1937 a 1967 Ana Catarina Francisco / Cleia Detry / César Neves / Andrea Martins / Mariana Diniz / José Morais Arnaud

959 Análise funcional de material lítico em sílex do castro de Vila Nova de S. Pedro (Azambuja, Portugal): uma primeira abordagem Rafael Lima

971 O recinto da Folha do Ouro 1 (Serpa) no contexto dos recintos de fossos calcolíticos alentejanos

António Carlos Valera / Tiago do Pereiro / Pedro Valério / António M. Monge Soares

\section{Proto-História}

987 Produção de sal marinho na Idade do Bronze do noroeste Português. Alguns dados para uma reflexão

Ana M. S. Bettencourt / Sara Luz / Nuno Oliveira / Pedro P. Simões / Maria Isabel C. Alves / Emílio Abad-Vidal

1001 A estátua-menir do Pedrão ou de São Bartolomeu do Mar (Esposende, noroeste de Portugal) no contexto arqueológico da fachada costeira de entre os rios Neiva e Cávado Ana M. S. Bettencourt / Manuel Santos-Estévez / Pedro Pimenta Simões / Luís Gonçalves

1015 O Castro do Muro (Vandoma/Baltar, Paredes) - notas para uma biografia de ocupação da Idade do Bronze à Idade Média

Maria Antónia D. Silva / Ana M. S. Bettencourt / António Manuel S. P. Silva / Natália Félix

1031 Do Bronze Final à Idade Média - continuidades e hiatos na ocupação de Povoados em Oliveira de Azeméis João Tiago Tavares / Adriaan de Man

1041 As faunas do final da Idade do Bronze no Sul de Portugal: leituras desde o Outeiro do Circo (Beja)

Nelson J. Almeida / Íris Dias / Cleia Detry / Eduardo Porfírio / Miguel Serra

1055 A Espada do Monte das Oliveiras (Serpa) - uma arma do Bronze Pleno do Sudoeste Rui M. G. Monge Soares / Pedro Valério / Mariana Nabais / António M. Monge Soares

1065 São Julião da Branca (Albergaria-a-Velha) - Investigação e valorização de um povoado do Bronze Final

António Manuel S. P. Silva / Paulo A. P. Lemos / Sara Almeida e Silva / Edite Martins de Sá

1083 Do castro de S. João ao Mosteiro de Santa Clara: notícia de uma intervenção arqueológica, em Vila do Conde Rui Pinheiro 
1095 O castro de Ovil (Espinho), um quarto de século de investigação - resultados e questões em aberto

Jorge Fernando Salvador / António Manuel S. P. Silva

1111 O Castro de Salreu (Estarreja), um povoado proto-histórico no litoral do Entre Douro e Vouga

Sara Almeida e Silva / António Manuel S. P. Silva / Paulo A. P. Lemos / Edite Martins de Sá

1127 Castro de Nossa Senhora das Necessidades (Sernancelhe): uma primeira análise artefactual Telma Susana O. Ribeiro

${ }_{1141}$ A cividade de Bagunte. O estado atual da investigação Pedro Brochado de Almeida

1153 Zoomorfos na cerâmica da Idade do Ferro no NW Peninsular: inventário, cronologias e significado Nuno Oliveira / Cristina Seoane

1163 Vasos gregos em Portugal: diferentes maneiras de contar a história do intercâmbio cultural na Idade do Ferro

Daniela Ferreira

1175 Os exotica da necrópole da Idade do Ferro do Olival do Senhor dos Mártires (Alcácer do Sal) no seu contexto regional

Francisco B. Gomes

\section{Antiguidade Clássica e Tardia}

1191 O uso de madeira como combustível no sítio da Quinta de Crestelos (Baixo Sabor): da Idade do Ferro à Romanização Filipe Vaz / João Tereso / Sérgio Simões Pereira / José Sastre / Javier Larrazabal Galarza / Susana Cosme / José António Pereira / Israel Espi

1207 Cultivos de Época Romana no Baixo Sabor: continuidade em tempos de mudança? João Pedro Tereso / Sérgio Simões Pereira / Filipe Santos / Luís Seabra / Filipe Vaz

1221 A casa romana na Hispânia: aplicação dos modelos itálicos nas províncias ibéricas Fernanda Magalhães / Diego Machado / Manuela Martins

1235 As pinturas murais romanas da Rua General Sousa Machado, n. ${ }^{5}$ 1, Chaves José Carvalho

1243 Trás do Castelo (Vale de Mir, Pegarinhos, Alijó) - Uma exploração agrícola romana do Douro

Tony Silvino / Pedro Pereira

1255 A sequência de ocupação no quadrante sudeste de Bracara Augusta: as transformações de uma unidade doméstica Lara Fernandes / Manuela Martins

1263 Os Mosaicos com decoração geométrica e geométrico-vegetalista dos sítios arqueológicos da área do Conuentus Bracaraugustanus. Novas abordagens quanto à conservação, restauro, decoração e datação Maria de Fátima Abraços / Licínia Wrench

1277 “Casa Romana” do Castro de São Domingos (Cristelos, Lousada): Escavação, Estudo e Musealização Paulo André de P. Lemos

1291 A arqueobotânica no Castro de Guifões (Matosinhos, Noroeste de Portugal): O primeiro estudo carpológico

Luís Seabra / Andreia Arezes / Catarina Magalhães / José Varela / João Pedro Tereso 
1305 Um Horreum Augustano na Foz do Douro (Monte do Castelo de Gaia, Vila Nova de Gaia) Rui Ramos

1311 Ponderais romanos na Lusitânia: padrões, formas, materiais e contextos de utilização Diego Barrios Rodríguez

1323 Um almofariz centro-itálico na foz do Mondego

Marco Penajoia

1335 Estruturas romanas de Carnide - Lisboa Luísa Batalha / Mário Monteiro / Guilherme Cardoso

1347 O contexto funerário do sector da "necrópole NO" da Rua das Portas de S. Antão (Lisboa): o espaço, os artefactos, os indivíduos e a sua interconectividade na interpretação do passado Sílvia Loja, José Carlos Quaresma, Nelson Cabaço, Marina Lourenço, Sílvia Casimiro, Rodrigo Banha da Silva, Francisca Alves-Cardoso

${ }_{1361}$ Povoamento em época Romana na Amadora - resultados de um projeto pluridisciplinar Gisela Encarnação / Vanessa Dias

1371 A Arquitectura Residencial em Mirobriga (Santiago do Cacém): contributo a partir de um estudo de caso Filipe Sousa / Catarina Felício

${ }_{1385}$ O fim do ciclo. Saneamento e gestão de resíduos nos edifícios termais de Mirobriga (Santiago do Cacém)

Catarina Felício / Filipe Sousa

1399 Balsa, Topografia e Urbanismo de uma Cidade Portuária Vítor Silva Dias / João Pedro Bernardes / Celso Candeias / Cristina Tété Garcia

1413 No Largo das Mouras Velhas em Faro (2017): novas evidências da necrópole norte de Ossonoba e da sua ocupação medieval Ricardo Costeira da Silva / Paulo Botelho / Fernando Santos / Liliana Nunes

1429 Instrumentos de pesca recuperados numa fábrica de salga em Ossonoba (Faro) Inês Rasteiro / Ricardo Costeira da Silva / Paulo Botelho

1439 A Necrópole Romana do Eirô, Duas Igrejas (Penafiel): intervenção arqueológica de 2016 Laura Sousa / Teresa Soeiro

1457 Ritual, descarte ou afetividade? A presença de Canis lupus familiaris na Necrópole Noroeste de Olisipo (Lisboa)

Beatriz Calapez Santos / Sofia Simões Pereira / Rodrigo Banha da Silva / Sílvia Casimiro / Cleia Detry / Francisca Alves Cardoso

1467 Dinâmicas económicas em Bracara na Antiguidade Tardia Diego Machado / Manuela Martins / Fernanda Magalhães / Natália Botica

1479 Cerâmicas e Vidros da Antiguidade Tardia do Edifício sob a Igreja do Bom Jesus (Vila Nova de Gaia) Joaquim Filipe Ramos

1493 Novos contributos para a topografia histórica de Mértola no período romano e na Antiguidade Tardia Virgílio Lopes

\section{8. Época Medieval}

1511 Cerâmicas islâmicas no Garb setentrional "português": algumas evidências e incógnitas Constança dos Santos / Helena Catarino / Susana Gómez / Maria José Gonçalves / Isabel Inácio / Gonçalo Lopes / Jacinta Bugalhão / Sandra Cavaco / Jaquelina Covaneiro / Isabel Cristina Fernandes / Ana Sofia Gomes 
1525 Contributo para o conhecimento da cosmética islâmica, em Silves, durante a Idade Média Rosa Varela Gomes

1537 Yábura e o seu território - uma análise histórico-arqueológica de Évora entre os séculos VIII-XII José Rui Santos

1547 A encosta sul do Castelo de Palmela - resultados preliminares da escavação arqueológica Luís Filipe Pereira / Michelle Teixeira Santos

1559 A igreja de São Lourenço (Mouraria, Lisboa): um conjunto de silos e de cerâmica medieval islâmica

Andreia Filipa Moreira Rodrigues

1571 O registo material de movimentações populacionais no Médio Tejo, durante os séculos XII-XIII. Dois casos de "sunken featured buildings", nos concelhos de Cartaxo e Torres Novas Marco Liberato / Helena Santos / Nuno Santos

1585 O nordeste transmontano nos alvores da Idade média. Notas para reflexão Ana Maria da Costa Oliveira

1601 Sepulturas escavadas na rocha do Norte de Portugal e do Vale do Douro: primeiros resultados do Projecto SER-NPVD

Mário Jorge Barroca / César Guedes / Andreia Arezes / Ana Maria Oliveira

1619 "Portucalem Castrum Novum" entre o Mediterrâneo e o Atlântico: o estudo dos materiais cerâmicos alto-medievais do arqueossítio da rua de D. Hugo, nํ. 5 (Porto) João Luís Veloso

1627 A Alta Idade Média na fronteira de Lafões: notas preliminares sobre a Arqueologia no Concelho de Vouzela

Manuel Luís Real / Catarina Tente

1641 Um conjunto cerâmico medieval fora de portas: um breve testemunho aveirense Susana Temudo

${ }_{1651}$ Os Lóios do Porto: uma perspetiva integrada no panorama funerário da Baixa Idade Média à Época Moderna em meios urbanos em Portugal

Ana Lema Seabra

1659 O Caminho Português Interior de Santiago como eixo viário na Idade Média Pedro Azevedo

1665 Morfologia Urbana: Um exercício em torno do Castelo de Ourém André Donas-Botto / Jaqueline Pereira

1677 Intervenção arqueológica na Rua Marquês de Pombal/Largo do Espírito Santo (Bucelas, Loures)

Florbela Estêvão / Nathalie Antunes-Ferreira / Dário Ramos Neves / Inês Lisboa

1691 O Cemitério Medieval do Poço do Borratém e a espacialidade funerária na cidade de Lisboa Inês Belém / Vanessa Filipe / Vasco Noronha Vieira / Sónia Ferro / Rodrigo Banha da Silva

1705 Um Espaço Funerário Conventual do séc. XV em Lisboa: o caso do Convento de São Domingos da Cidade Sérgio Pedroso / Sílvia Casimiro / Rodrigo Banha da Silva / Francisca Alves Cardoso

\section{9. Época Moderna e Contemporânea}

1721 Arqueologia Moderna em Portugal: algumas reflexões críticas em torno da quantificação de conjuntos cerâmicos e suas inferências históricas e antropológicas Rodrigo Banha da Silva / André Bargão / Sara da Cruz Ferreira

1733 Faianças de dois contextos entre os finais do século XVI e XVIII do Palácio dos Condes de Penafiel, Lisboa

Martim Lopes / Tomás Mesquita 
1747 Um perfil de consumo do século XVIII na foz do Tejo: O caso do Mercado da Ribeira, Lisboa Sara da Cruz Ferreira / Rodrigo Banha da Silva / André Bargão

1761 Os Cachimbos dos Séculos XVII e XVIII do Palácio Mesquitela e Convento dos Inglesinhos (Lisboa)

Inês Simão / Marina Pinto / João Pimenta / Sara da Cruz Ferreira / André Bargão / Rodrigo Banha da Silva

1775 "Tomar os fumos da erua que chamão em Portugal erua sancta». Estudo de Cachimbos provenientes da Rua do Terreiro do Trigo, Lisboa

Miguel Martins de Sousa / José Pedro Henriques / Vanessa Galiza Filipe

1787 Cachimbos de Barro Caulínitico da Sé da Cidade Velha (República de Cabo Verde)

Rodrigo Banha da Silva / João Pimenta / Clementino Amaro

1801 Algumas considerações sobre espólio não cerâmico recuperado no Largo de Jesus (Lisboa) Carlos Boavida

1815 Adereços de vidro, dos séculos XVI-XVIII, procedentes do antigo Convento de Santana de Lisboa (anéis, braceletes e contas)

Joana Gonçalves / Rosa Varela Gomes / Mário Varela Gomes

1837 Da ostentação, luxo e poder à simplicidade do uso quotidiano: arqueologia e simbologia de joias e adornos da Idade Moderna Portuguesa Jéssica Iglésias

1849 Os amuletos em Portugal - dos objetos às superstições: o coral vermelho Alexandra Vieira

1865 Cerâmicas de Vila Franca de Xira nos séculos XV e XVI Eva Pires

1879 «Não passa por teu o que me pertence». Marcas de individualização associadas a faianças do Convento de Nossa Senhora de Aracoeli, Alcácer do Sal Catarina Parreira / Íris Fragoso / Miguel Martins de Sousa

1891 Cerâmica de Leiria: alguns focos de produção

Jaqueline Pereira / André Donas-Botto

1901 Os Fornos na Rua da Biquinha, em Óbidos Hugo Silva / Filipe Oliveira

1909 A casa de Pêro Fernandes, contador dos contos de D. Manuel I: o sítio arqueológico da Silha do Alferes, Seixal (século XVI) Mariana Nunes Ferreira

1921 O Alto da Vigia (Sintra) e a vigilância e defesa da costa Alexandre Gonçalves / Sandra Santos

1937 O contexto da torre sineira da Igreja de Santa Maria de Loures Paulo Calaveira / Martim Lopes

1949 A Necrópole do Hospital Militar do Castelo de São Jorge e as práticas funerárias na Lisboa de Época Moderna Susana Henriques / Liliana Matias de Carvalho / Ana Amarante / Sofia N. Wasterlain

1963 SAND - Sarilhos Grandes Entre dois Mundos: o adro da Igreja e a Paleobiologia dos ossos humanos recuperados

Paula Alves Pereira / Roger Lee Jesus / Bruno M. Magalhães

1975 Expansão urbana da vila de Cascais no século XVII e XVIII: a intervenção arqueológica na Rua da Vitória no 15 a 17

Tiago Pereira / Vanessa Filipe

1987 Novos dados para o conhecimento do Urbanismo de Faro em época Moderna Ana Rosa 
1995 Um exemplo de Arqueologia Urbana em Alcoutim: o Antigo Edifício dos CTT Marco Fernandes / Marta Dias / Alexandra Gradim / Virgílio Lopes / Susana Gómez Martínez

2007 Palácio dos Ferrazes (Rua das Flores/Rua da Vitória, Porto): a cocheira de Domingos Oliveira Maia

Francisco Raimundo

2021 As muitas vidas de um edifício urbano: História, Arqueologia e Antropologia no antigo Recreatório Paroquial de Penafiel Helena Bernardo / Jorge Sampaio / Marta Borges

2035 O convento de Nossa Senhora da Esperança de Ponta Delgada: o contributo da arqueologia para o conhecimento de um monumento identitário João Gonçalves Araújo / N’Zinga Oliveira

2047 Arqueologia na ilha do Corvo... em busca da capela de Nossa Senhora do Rosário Tânia Manuel Casimiro / José Luís Neto / Luís Borges / Pedro Parreira

2059 Perdidos à vista da Costa. Trabalhos arqueológicos subaquáticos na Barra do Tejo Jorge Freire / José Bettencourt / Augusto Salgado

2071 Arqueologia marítima em Cabo Verde: enquadramento e primeiros resultados do projecto CONCHA

José Bettencourt / Adilson Dias / Carlos Lima / Christelle Chouzenoux / Cristóvão Fonseca / Dúnia Pereira / Gonçalo Lopes / Inês Coelho / Jaylson Monteiro / José Lima / Maria Eugénia Alves / Patrícia Carvalho / Tiago Silva

2085 Trabalhos arqueológicos na Cidade Velha (Ribeira Grande de Santiago, Cabo Verde): reflexões sobre um projecto de investigação e divulgação patrimonial André Teixeira / Jaylson Monteiro / Mariana Mateus / Nireide Tavares / Cristovão Fonseca / Gonçalo C. Lopes / Joana Bento Torres / Dúnia Pereira / André Bargão / Aurélie Mayer / Bruno Zélie / Carlos Lima / Christelle Chouzenoux / Inês Henriques / Inês Pinto Coelho / José Lima / Patrícia Carvalho / Tiago Silva

2103 A antiga fortificação de Quelba / Khor Kalba (E.A.U.). Resultados de quatro campanhas de escavações, problemáticas e perspectivas futuras Rui Carita / Rosa Varela Gomes / Mário Varela Gomes / Kamyar Kamyad

2123 Colónias para homens novos: arqueologia da colonização agrária fascista no noroeste ibérico Xurxo Ayán Vila / José Mạ . Señorán Martín 


\title{
UM PERFIL DE CONSUMO DO SÉCULO XVIII NA FOZ DO TEJO: O CASO DO MERCADO DA RIBEIRA, LISBOA
}

\author{
Sara da Cruz Ferreira ${ }^{1}$, Rodrigo Banha da Silva ${ }^{2}$, André Bargão ${ }^{3}$
}

\begin{abstract}
RESUMO
Nos finais de 2003 e em 2004, no âmbito da remodelação interna da ala este do Mercado da Ribeira, em Lisboa, foram colocados a descoberto os remanescentes do Forte e Cais de São Paulo. Estas estruturas encontravam-se erguidas sobre uma campanha de aterros, que visou reerguer a destruída freguesia de São Paulo após o terramoto de 1755 .

Nos estratos de nivelamento foi identificado um amplo conjunto cerâmico com cronologias homogéneas, compreendidas na primeira metade do século XVIII, exemplificativo do perfil de consumo da Ribeira Ocidental de Lisboa, sendo este conjunto o elemento de análise no presente estudo. Acresce, também, o objectivo de trazer à comunidade arqueológica diversas categorias cerâmicas que pautam estes quotidianos e que tão escassamente integram estudos de arqueologia de época moderna.
\end{abstract}

Palavras-chave: Arqueologia Urbana, Arqueologia Moderna, Cerâmicas Modernas, Ribeira de Lisboa.

\begin{abstract}
In late 2003 and in 2004, urban remodelation of the east wing of Mercado da Ribeira revealed the remains of São Paulo's Fort and Quay. Both structures were built on top of a land filing originated by post-1755 Lisbon Earthquake city reconstruction of S. Paulo's parish.

In the layers a large set of pottery was collected, enclosing chronologies within the first half of the $18^{\text {th }}$ century, a fine example of consumption pattern of Lisbon's Western Riverfront here displayed, including some pottery categories present in $18^{\text {th }}$ century daily life, often neglected by Early Modern Archaeology studies.

Keywords: Urban Archaeology, Early Modern Archaeology, Early Modern Pottery, Archaeological riverfront contexts.
\end{abstract}

\section{O SÍTIO ARQUEOLÓGICO DO MERCADO DA RIBEIRA, EM LISBOA}

O edifício do Mercado da Ribeira encontra-se edificado na actual freguesia da Misericórdia, antiga freguesia de São Paulo. A estrutura é delimitada a norte pela Rua da Ribeira Nova e a sul pela Avenida 24 de Julho (Figura 1).

$\mathrm{Na}$ transição de 2003 para 2004, o projecto de remodelação interna da ala este da infra-estrutura comercial exigiu a realização de trabalhos de peritagem arqueológica e consequente escavação em área, com- portando $765 \mathrm{~m}^{2}$. Esta empreitada, adjudicada à empresa ERA Arqueologia, S.A., subdividiu o espaço em dois sectores, nos quais foram identificados dois momentos de ordenamento urbano distintos (Charneca, Miguel \& Pinto, 2004).

O primeiro corresponde a uma sucessão de depósitos de aterro assentes sobre a praia fluvial, sobre o qual é construída uma calçada em sentido NO-SE no fim do século XVII (Ferreira, 2015, p. 43). Após uma acção de aterro de todo este espaço, foram erguidas, após o terramoto de 1755, duas estruturas: uma fracção do forte de São Paulo, a norte do denominado

\footnotetext{
1. Bolseira de Doutoramento FCT SFRH/BD/137142/2018. CHAM - NOVA FCSH; sara.isabel91@hotmail.com

2. CAL/DPC/CML. Departamento de História NOVA FCSH. CHAM FCSH e UAç.; rbds@fcsh.unl.pt

3. Bolseiro de Doutoramento FCT SFRH/BD/133757/2017. CHAM - NOVA FCSH; andrebargao@gmail.com
} 
Sector 1, e o Cais de São Paulo, a sul, no Sector 2, que permaneceram no registo cartográfico até à segunda metade do século XIX para depois serem anuladas por uma extensa campanha de aterro (Figura 2). Em 1882, o edifício em arquitectura do ferro, o Mercado da 24 de Julho, marca definitivamente o novo perfil urbano e comercial desta zona ribeirinha (Ferreira, 2015, p. 107).

\section{OS MATERIAIS ARQUEOLÓGICOS}

$\mathrm{Na}$ extremidade NO do Sector $\mathrm{I}$ foi identificada uma porção murária do Forte de São Paulo, servindo actualmente de alicerce do espaço de restauração/comercial contemporâneo. Apesar da análise estrutural ter sido altamente limitada por distintas condicionantes logísticas da empreitada, optou-se, simultaneamente, pela análise de todas as U.E'S que adossavam ao paramento externo do Forte, com o objectivo de aferir cronologias construtivas para o mesmo.

Alicerçada nos pressupostos metodológicos do Número Mínimo de Indivíduos (NMI - Orton, 1980; Orton \& Tyers, 1993), a organização do acervo passou pela seriação em grandes categorias de produção, tipologias, decorações, fabricos e consequentes atribuições de proveniência. Do total de 12975 fragmentos contabilizaram-se $7726 \mathrm{NMI}$, na maioria referentes a produções nacionais (faiança, cerâmica comum de barro vermelho fosco, cerâmica vidrada - Gráfico 1). Não obstante a diversidade tipológica e a vasta gama da geografia das produções presentes, o conjunto permite desenhar uma proposta de perfil de consumo na Ribeira Ocidental de Lisboa na primeira metade de setecentos.

\subsection{As Faianças Portuguesas}

O acervo exumado e aqui em estudo é maioritariamente formado por faiança portuguesa, representada por vasta panóplia formal referente a louça de uso à mesa: predominam no conjunto os pratos (2459 NMI), as tigelas (580 NMI) e as covilhetes (551 $\mathrm{NMI}$ ), atingindo menor expressividade os jarros (91 NMI), escudelas (16 NMI), salseiros/especieiros (12 $\mathrm{NMI}$ ) e as terrinas (3 NMI). A par desta categoria funcional de mesa foi igualmente possível registar outras formas: 48 bispotes, 286 bacias, 46 tampas, 27 pequenos potes, 8 castiçais e 2 boiões (NMI). De referir ainda 88 indivíduos indeterminados.

Esta análise foi cruzada com o levantamento decorativo, sendo este um elemento determinante para aferir as cronologias de produção, recorrendo-se, embora não somente, à proposta de categorização crono-estilística mais recente (Casimiro, 2013). Em função desta opção metodológica, registou-se uma maior presença de decoração minimalista em azul-cobalto circunscrita aos fundos e bordos, mas igualmente, no centro das peças, aplicada a partir do fim do século XVII. Deste modo se classificaram dentro do grupo "motivos geométricos e fitomórficos simples" 308 indivíduos (MRLX-05o; 068; 087 e o88), 253 no grupo de "semicírculos concêntricos" (MRLXo3/o4-070 e 079) e, com menor expressão, 33 indivíduos decorados por "pétalas e folhagem" (MRLXo3/o4-073) e dois pequenos fragmentos com "pequenas espirais".

No fim do século XVII, a produção de faiança portuguesa introduziu o óxido de manganês/castanho vinhoso, largamente aceite e empregue na centúria seguinte. Com esta particularidade, foram contabilizados 1104 indivíduos com superfícies decoradas com pequenos apontamentos de manganês (MRLXo3/o4-059; 062 e 078).

Simultaneamente à aplicação deste óxido nas produções nacionais, permaneceram em produção e circuito peças com decorações em azul cobalto amplamente difundidas a partir do fim de seiscentos e século seguinte. Exemplo desta simbiose decorativa, identificaram-se 448 indivíduos com o elemento de "contas" (MRLXo3/04-063; 064 e 08o), 232 com "faixas barrocas" (MRLXo3/O4-O53 e MRLXo3/O4-084)e, por fim, 57 indivíduos com a temática de "rendas".

Num mundo em constante contacto e interações, a louça portuguesa inspirou-se em determinados elementos decorativos já presentes na porcelana chinesa de então, nomeadamente as gramáticas de "pêssegos" e "aranhões", aqui representadas por 49 indivíduos (MRLXo3/o4-083 e o86.), bem como o "desenho miúdo", obtido através de finos traços a manganês, patente em 59 indivíduos (MRLXo3/ 04-056).

A vasta colecção de faiança portuguesa permite reconhecer outros grupos decorativos que podem ser interpretados como peças de encomenda, aspecto reforçado por representações heráldicas em 17 indivíduos (MRLXo3/o4-o61).

Apesar da elevada fragmentação das peças, enumeram-se 12 salseiros/especieiros (MRLXo3/O4-054) sem aparente decoração. Esta ausência corrobora a datação atribuída, inserindo-se nos horizontes de seiscentos e setecentos. 


\subsection{As cerâmicas de barro vermelho fosco}

As produções de barro vermelho sem revestimento produzidas nas olarias lisboetas estão representadas por 1756 indivíduos, sendo o grupo composto maioritariamente por morfologias ligadas à confecção alimentar, como os 288 fogareiros (MRLXo3/o4102), 267 tachos (MRLXo3/o4-09o; o91 e 10), 264 panelas (MRLXo3/o4-099; 108 e 112) e 59 caçoilas (MRLXo3/04-100).

No âmbito da restante cerâmica de barro vermelho não vidrada (da água, de armazenamento, de apoio e multiusos) identificaram-se 73 cântaros (MRLXo3/O4-118), 57 alguidares (MRLXo3/o4120), 35 potes (MRLXo3/O4-104; 113 e 122), 34 testos, 6 bilhas MRLXo3/o4-116), 5 garrafas (MRLXo3/o4124), 2 bispotes, 2 bacias e 4 alcatruzes (MRLXo3/O4110) e um copo de medida (MRLXo3/o4-111).

Os quotidianos à mesa do início de setecentos incluíam também, embora minoritariamente, morfologias como os prato-tampa, púcaros para o consumo de líquidos, covilhetes em chacota e especieiros/salseiros, cada uma destas formas, com valores de representatividade reduzidos, entre $15 \mathrm{e}$ 4 NMI (MRLXo3/O4-097).

\subsection{As cerâmicas comuns vidradas}

A par da produção regional de cerâmica comum de barro vermelho sem revestimento, o conjunto exumado no Mercado da Ribeira compreende, igualmente, exemplares diversos revestidos a vidrado plumbífero verde e/ou melado em 290 indivíduos oriundos das olarias lisboetas. Se no grupo da cerâmica de barro vermelho sem revestimento o predomínio formal recai em objectos ligados à confecção alimentar, no caso dos elementos vasculares vidrados observa-se a aplicabilidade desta técnica, que proporciona impermeabilização e maior facilidade na lavagem, de que se contabilizaram em 63 alguidares (63 - MRLXo3/04-095 e 105) e 43 bispotes (MRLXo3/04-098 e 114). Com menor expressão observam-se ainda panelas, tachos e caçoilas, com 10, 15 e 24 indivíduos, respectivamente, a que acrescem 19 potes (MRLXo3/o4-127) e apenas um indivíduo de garrafa (MRLXo3/O4-O92)

Não obstante as produções lisboetas, o conjunto integra, ainda que com menor expressão, produções flamengas de pasta alaranjada, depurada e com elementos não plásticos de pequeno e médio calibre. Estas características encontram-se presentes numa porção de bordo vertical de tigela de tendência tron- cocónica, revestida a vidrado espesso, brilhante e de coloração castanho-melado, com produção balizada entre a segunda metade do século XV e o decurso do século XVI (MRLXo3/o4-123) (Gomes \& Gomes, 1995, pp. 324-347).

De geografias mais próximas foi individualizado um fragmento (MRLXo3/o4-107) mostrando pasta rosada e compacta, coberto por esmalte espesso, brilhante e cinzento/esverdeado, com craquelet. O exemplar enquadra-se nas produções "Sevilha White" produzidas na cidade homónima entre 1530 e 1650 , e inspiradas nas peças esmaltadas a branco de Faenza, Itália (Ernst, 2011, pp. 85-86).

\subsection{Os cachimbos em barro caulínico}

A introdução de novos hábitos nos quotidianos europeus de Época Moderna justifica a presença de cachimbos nas estratigrafias aqui em estudo. Esta colecção, das mais expressivas em território português, é composta por 909 fragmentos de cachimbos em caulino produzidos na primeira metade de setecentos nas oficinas britânicas e holandesas (Pinto, et. al., 2011, pp. 41-47).

À primeira publicação deste conjunto ceramológico (idem) acrescentaram-se mais seis fragmentos de hastes proximais e cinco hastes decoradas com impressões de denticulados incisos. Aos fornilhos acresce um fragmento britânico (MRLXo3/o4[1230]223) com decoração denticulada incisa a delimitar o bordo e uma marca impressa de produção “RT”” no pedúnculo, remetendo para as elaborações de "Robert Tippet and Family", datadas de entre 1680-176o, idêntico aos exemplares recolhidos em Port Royal, na Jamaica (Fox, 1998, pp. 284-287).

\subsection{Os azulejos}

Nas unidades em estudo foram contabilizados 200 fragmentos de azulejo, cujas temáticas decorativas delineadas sobre as superfícies integra a maioria no grupo de “Azulejos de Padrão", portanto encerrando uma datação dos finais do século XVII e séc. XVIII. Assim se contabilizaram 103 fragmentos com decorações a azul de cobalto, com contornos delineados a manganês (MRLXo3/04-224 e 225); um outro subgrupo engloba 49 fragmentos e distingue-se do grupo anterior pela inclusão na cromática do amarelo (MRLXo3/o4-226 e 227).

Os restantes exemplares correspondem a espécimes com cronologias de produção mais recuadas, dos finais do século XV e da centúria seguinte. Inserem- 
-se nestes os 21 fragmentos de tipo "enxaquetado" e o único exemplar do tipo "Aresta" ou "Cuenca" (MRLXo3/o4-228).

\subsection{Os vidros}

No que concerne aos materiais vítreos, contabilizaram-se 172 indivíduos, dos quais 122 correspondentes a garradas cilíndricas e alongadas, com bordo composto por marisas de perfil triangular (MRLXo3/o4205 e 208), elemento datável do século XVIII e, ainda, um exemplar com gargalo em anel aplicado (MRLXo3/o4-209) (Medici, 2011, p. 337).

As garrafas com perfil mais compacto, do tipo apelidado do "cebolas" ou "cabaça", está representado por 13 indivíduos (MRLXo3/o4-210). Estas peças apresentam fundo em ônfalo com marca de pontel, elementos associados às produções pós-1650.

Com valores diminutos, registaram-se duas garrafas de perfil quadrangular datadas da primeira metade do século XVIII (Medici, 2011, p. 336).

A par das garrafas, registaram-se 11 frascos de vidro (MRLXo3/o4-211 e 216), um copo de pé alto (MRLXo3/o4-206) e um copo raso (MRLXo3/o4214), datados dos séculos XVII e XVIII (Medici, 2011, p. 331), 6 elementos de vidraça translúcida verde-água que, devido à elevada taxa de fragmentação e ausência de características conservadas, não permite determinar datação de produção. Este dado inviabiliza, desafortunadamente, a atribuição morfológica e tipológica, e consequente datação, de 32 indivíduos.

\subsection{As porcelanas chinesas}

O conjunto de porcelana chinesa compõe-se por 102 indivíduos. Para o consumo de alimentos à mesa foram contadas 38 tigelas e 39 pratos. Estes valores contrastam com os recipientes destinados à ingestão de líquidos espelhados apenas por oito pequenas tigelas/copos sem asa lateral (MRLXo3/O4-152 e 154) e duas chávenas com este elemento (MRLXo3/o4168): se os primeiros, sem elemento de pega, integram reportórios orientais, as chávenas onde se verifica a pega dizem respeito a formas de influência europeia ainda que de produção asiática setecentista. Todavia, identificaram-se ainda, formas associadas ao aparato nos quotidianos, como a presença de 4 grandes potes (MRLXo3/o4-159) e o fundo de uma pequena caixa.

No decorrer de setecentos, banaliza-se o consumo de bebidas quentes no quotidiano europeu, prática que fez surgir novas tipologias nas produções orientais, nas quais se integram as duas chávenas identificadas, assim como 3 pequenas tampas (MRLXo3/o4-178), que vedavam os copos altos nos quais se degustava chocolate quente (Antunes, 2000, p. 27).

Nos finais do século XVII e no decorrer do século XVIII, os espécimes eram pintados a azul a delinear temáticas florais, ao agrado do mercado Europeu, de que são exemplo os fundos de prato MRLXo3/o4155; 172 e 181. Contudo, às gramáticas a azul de cobalto descritas, o recuso a esmaltes polícromos é vulgarizado a partir do final da centúria de seiscentos. Neste grupo inserem-se os exemplares, cujo destaque são o recurso a decorações pintadas a verde: "Família Verde" (MRLXo3/o4-164) e "Família Chocolate" (MRLXo3/o4-163), como os exemplares de inspiração Japonesa que ostentam decorações a azul, vermelho e dourado, características das produções de Imari Chinês (MRLXo3/o4-177).

Em contraponto à policromia da Dinastia Qing, no mesmo período surgiram peças que apresentam a totalidade do corpo branca, sem recurso a qualquer esmalte colorido, designadas por "casca de ovo" ou "Blanc de Chine" (MRLXo3/O4-161), onde prevalece um certo gosto simplicista oriental. Nestas elaborações se insere também a tigela de perfil completo MRLXo3/o4-152, que difere do restante conjunto por apresentar uma decoração floral em relevo, sendo enquadrável nas peças fabricadas nos finais da dinastia Ming, designadas por Dehua Wares (Valenstein, 1989, p. 203).

Nos inícios do século XVII, a afirmação mercantil da Companhia Holandesa das Índias Orientais (V.O.C.) e a consequente massificação da produção, fizeram surgir uma gramática decorativa na porcelana chinesa muito própria deste período, numa clara tentativa de simplificar e esquematizar o processo decorativo. As peças apresentam decorações repartidas em cartelas, que irradiam para um medalhão central, reproduzido no fundo dos recipientes (MRLXo3/o4173), com gramáticas vegetalistas e zoomórficas.

O conjunto de porcelanas chinesas exumado no Mercado da Ribeira destaca-se do restante espólio exumado, pela presença de exemplares com datações mais recuadas. A identificação de um número considerável de exemplares da Dinastia Ming incita-nos, desde logo, a explicar a presença destas peças por encerrarem um mais longo "período de vida", resultante de um manuseamento mais cuidado, de uma posição de maior destaque nos quotidianos e, sobretudo, através de uma transmissão pluri-geracional. 
Neste âmbito identificaram-se peças, de bordos delimitados em cartelas prismáticas (MRLXo3/O4-183), enquadráveis das produções executadas nos últimos anos da Dinastia Ming e primeiros da Qing, designados por Período de Transição (Valenstein, 1989, p. 200). Relativamente às produções Ming mais recuadas, características do século XVI e dos reinados de Jiajing (MRLXo3/o4-171) e Wanli, inserem-se 9 peças que apresentam o bordo com delimitações fitomórficas, assim como 10 indivíduos que apresentam temáticas zoomórficas, naturalistas e paisagísticas, inscritas por um medalhão central, delimitado ao centro do fundo das peças (MRLXo3/o4-153; 162; 166 e 169) e, por fim, um fragmento de bojo de um grande pote com banda fitomórfica, na qual se definiram rectângulos entrecruzados, preenchidos a azul de cobalto, característico do final do reinado do imperador Jiajing (Matos, 1996).

\subsection{As produções lígures}

Identificou-se um curioso conjunto composto por 73 peças, claramente individualizáveis do restante conjunto por apresentarem as superfícies cobertas por um espesso esmalte azul-esverdado, a revestir uma pasta depurada de tonalidade amarelada. As características descritas permitem-nos integrá-las nas produções das olarias de Albisola, Savona e Génova, na Ligúria (Bercero \& Alaix, 2010, pp. 26-27), no caso do Mercado da Ribeira repartido pelas tipologias que compõem as formas "de mesa", ou seja, 34 pratos; 17 tigelas; 2 taças; 2 tampas, 1 fruteira e 11 indivíduos indeterminados (NMI).

Com base nas propostas crono-estilísticas de Barcero e Alaix (2010), no conjunto assinala-se a presença de peças com: Scenografia Barroca, com delimitações de enquadramentos paisagísticos/aquáticos a par de elementos arquitectónicos, com cronologias de produção do fim do século XVII e início da centúria seguinte (MRLXo3/o4-185; 192; 194); Calligrafico a Tapezaria, que se pauta pela inspiração oriental, com representação de elementos naturalistas e vegetalistas, cenas bíblicas ou mitológicas (MRLXo3/o4184; 186; 187; 193; 196; 197; 202 e 204), elaboradas em meados do século XVII e até 1717 (Bercero e Alaix, 2010, pp. 44-46); de tendência Calligrafico Naturalístico, isto é, imitações/inspiração de paisagens chinesas naturalísticas e zoomórficas (MRLXo3/o4199 e 201), partilhando, genericamente, a datação do grupo decorativo anterior (Bercero \& Alaix, 2010, pp.40-42); no domínio da decoração heráldica regis- tou-se um fragmento (MRLXo3/o4-200) que exibe o brasão de armas da cidade de Savona (Bercero \& Alaix, 2010, pp. 72-74); por fim, particularizam-se dois fragmentos que apresentam marca pintada de olaria do tipo Lanterna, símbolo das oficinas de Albisola (MRLXo3/O4-199 e 201), a par do grafismo de “asterisco" (MRLXo3/O4-[1349]-192).

\subsection{As produções europeias em grés}

No "universo objectual" que compõe o acervo do Mercado da Ribeira, foram analisados 23 indivíduos em grés com particularismos que permitem reconhecer quatro centros produtores ingleses e um germânico.

No que concerne às Ilhas Britânicas, mencione-se a produção White Salt-Glazed composta por pasta e vidrado de coloração branca, presente em servições de chá produzidos entre 1690-1770 (Skerry \& Hood, 2009, pp. 97-99) (MRLXo3/o4-133 e 229).

Seis indivíduos de garrafa (MRLXo3/o4-129 a 131 e 341) encontram paralelos nas produções Fulham Wares ou Brown Salt Glazed, distinguíveis dos anteriores pela pasta clara e granulosa sobre a qual foi aplicado revestimento em grés "salpicado", variando entre o castanho, amarelo e verde (MRLXo3/o4340), executados entre 1675/169o e 1775 (Hume, 1970, p. 114).

Sete peças de pasta laranja, com vidrado brilhante, de aspecto metálico e de tom castanho que exibe decoração modelada, encontram paralelos formais e estilísticos nas olarias que integram as Nottingham Wares, particularmente activas na centúria de setecentos (Hume, 1970, p. 180). Qualquer deles respeita a canecas (MRLXo3/O4-138 e 139) profusamente decoradas por motivos incisos (MRLXo3/o4-337 e 338).

As produções germânicas, nomeadamente da região renana de Westerwald, surgem com alguma expressão no contexto de aterro ribeirinho aqui em análise. Neste sentido, contabilizaram-se quatro garrafas (MRLXo3/O4-132 e 134), um bispote (MRLXo3/o4-37) e oito fragmentos morfologicamente indeterminados. As produções destas oficinas situam-se entre o século XVII e a primeira metade de oitocentos (Hinton, 2012, pp.6-11), mostrando pastas cinzentas claras e vidrado brilhante, variável entre o azul de cobalto e roxo de manganês, sendo possível sugerir uma intenção e/ou inspiração de peças vítreas (MRLXo3/o4-320-325). 


\subsection{As anforetas sevilhanas}

A intenção de identificar centros produtores e respetivas cronologias permitiu determinar a presença de 12 contentores cerâmicos de pasta porosa e acabamento branco de superfície, sendo estes elementos integrantes das produções da bacia do Guadalquivir (MRLXo3/o4-140; 144; 145; 147; 148; 149 e 151). Apesar das variadas designações (anforeta, botija ou olive jar, entre outras), estes vasos de tendência globular correspondem a um recipiente fundamental na conservação, armazenamento e transporte de inúmeros bens alimentares. $\mathrm{O}$ reduzido custo de produção e facilidade de transporte, quer por via terrestre quer marítima/fluvial, determinaram a sua presença nas viagens e no comércio desde o século XV até ao século XVIII (Avery, 1997, pp. 131-132).

A versatilidade destas peças é reflectida na presença de vidrado de chumbo esverdeado no interior que sugere o transporte de produtos vinícolas (MRLXo3/o4-146 e 150). Ainda assim, as peças não vidradas destinar-se-iam, possivelmente, ao transporte de líquidos mais espessos e gordurosos, como o azeite (Goggin, 196o, p. 6).

\subsection{As cerâmicas comuns manuais}

Com particularismos que permitem a sua classificação como cerâmicas manuais, foram identificados 19 fragmentos, equivalentes a cinco indivíduos. Elaboradas em ambiente redutor, apresentam pasta escurecida e com abundantes inclusões não plásticas de pequeno e médio calibre, macroscopicamente identificadas como quartzos. Apresentam, igualmente, acabamento em técnica de brunido, sobre o qual foi aplicado engobe castanho/vermelho.

Trata-se de quatro de panelas (MRLXo3/o4-043 ao 046), com a presença de asas de rolo horizontais (MRLXo3/o4-048) e uma forma aberta (MRLXo3/o4-047). Estas peças encontram paralelos formais e tecnológicos em variadas intervenções arqueológicas de Lisboa, amplamente integrantes de contextos de entulho resultantes de 1755, sendo geralmente associadas pela investigação a ambientes esclavagistas e a uma origem no Brasil ou na Costa Atlântica Africana, todavia sem qualquer suporte de estudos arqueométricos (Oliveira \& Brochado, 2017, pp. 251-26o).

\subsection{As alcarrazas sevilhanas}

Destacamos, ainda, 10 fragmentos (dois indivíduos: MRLXo3/o4-233 e 235 e os fragmentos de bojo
MRLXo3/o4-235 e 234), de paredes finas compostas por pastas porosas de matriz calcária com tonalidade esbranquiçada-amarelada, não apresentando qualquer tipo de revestimento. Este tipo de peças, delicadas e bem torneadas, exibe diversos esquemas decorativos à base de molduras, incisões e depressões executadas através de diversos tipos de instrumentos de preensão sobre a pasta ainda fresca. Correspondem maioritariamente a formas globulares, com panças e colos destacados, bordos sub-triangulares, bases destacadas em disco e com asas adossadas à peça com decoração plástica aplicada. As características descritas permitem enquadrar os exemplares lisboetas em apreço nas produções de recipientes destinados a líquidos sevilhanas, designadas por $\mathrm{Al}$ carrazas. Peças deste tipo têm vindo a ser documentadas em contextos do século XV ao XVIII em Espanha, encontrando-se frequentemente representadas nas obras barrocas dos pintores Diego Velázquez (1599-166o), Francisco de Zurbarán (1598-1664) e Luis Meléndez (1716-178o) (Pleguezelo, 20oo, pp. 134-136).

\subsection{Os Thai Jars}

Foram identificadas duas peças (MRLXo3/04-041 e 042; e os fragmentos MRLXo3/O4: 298 ao 303), distinguíveis pela pasta compacta, em grés, de tonalidade bege, recobertas por um vidrado de tonalidade castanha escura a negra. Estes elementos são enquadráveis nas produções dos fornos de Sawakhalok (província do norte da actual Tailândia), onde foram produzidos grandes contentores em grés de formato globular, colo curto, grandes potes designados por Thai Jars, produzidos desde os fins do século XIV até 1584. Com a ascensão do império Khmer na cidade de Angkor, as produções dos fornos de Sawakhalok afluíam à cidade costeira de Ayutthaya, servindo este importante entreposto comercial de ponto redistribuidor, por inserido nas rotas comerciais do Índico (Craig, 2013, p. 12).

\section{O PERFIL DE CONSUMO DA RIBEIRA OCIDENTAL DE LISBOA, NA PRIMEIRA METADE DO SÉCULO XVIII}

A intensiva análise do espólio associado às U.E.'s conectadas com o vestígio do Forte de São Paulo permitiu datar a construção deste troço de muralha de meados da segunda metade do século XVIII (Ferreira, 2015). O cálculo da dispersão dos dados reuni- 
dos permitiu observar a incidência das datações de todos os grupos de fabrico na primeira metade do século XVIII. (Tabela 1 e Gráfico 2). Deste modo, o acervo colectado sugere representar um hipotético perfil de consumo da cidade dos momentos anteriores ao terramoto de 1755 da Ribeira Ocidental.

A primeira reflexão ao conjunto prende-se na incidência das produções em faiança portuguesa, reduzidas maioritariamente ao reportório tipológico de formas de uso individual à mesa para a degustação de alimentos, como os pratos, tigelas e covilhetes. Paralelamente, para a confecção alimentar, o acervo circunscreve-se às produções em barro vermelho, através das variantes formais de tachos, panelas, caçoilas e fogareiros.

Relativamente aos exemplares revestidos por vidrados plumbíferos, executados de igual forma sobre pastas vermelhas regionais, assomam, percentualmente, os alguidares como tipologia de apoio à cozinha, as bacias referentes à higiene pessoal e os bispotes de funcionalidade sanitária.

Com menor incidência contabilizam-se as produções exógenas circunscritas às cerâmicas lígures, às porcelanas chinesas e às produções em grés europeias e asiáticas, sobretudo integrantes do reportório formal dos espécimes individuais de uso à mesa, que, por comparação com a quantificação global do espólio recolhido, denuncia o carácter excepcional e minoritário da sua presença nos quotidianos setecentistas.

Noutro sentido, a elevada frequência percentual de porcelanas chinesas com datações da Dinastia Ming num nível de aterro da primeira metade do século XVIII equivale a uma realidade cada vez mais documentada na cidade. Os dados arqueológicos apontam-nos, portanto, para uma insuspeitada longevidade da vasculária chinesa podendo atingir os dois séculos, significando deste modo que percorreram os quotidianos lisboetas pretéritos mediante um manuseamento mais cuidado e/ou pelos mecanismos do sistema de transmissão multi-geracional.

As elaborações oleiras chinesas, aliás, traduzem também, através da sua relativa expressividade quantitativa o crescendo de mercado ganho em Portugal, por contraponto com os minoritários grupos cerâmicos e vítreos de origem europeia, sendo o panorama assaz contrastante com o verificado nos contextos lisboetas do séc. XVI, quando as elaborações espanholas, e em particular sevilhanas, dominavam um mesmo nicho.
Do acervo material sobressai o quadro conjuntural lisboeta anterior ao terramoto de 1755, onde assoma a vulgarização dos hábitos disseminados em resultado das ligações transatlânticas mantidas pela capital do Reino, de onde se salienta o consumo de tabaco por inalação mediante cachimbo, como a incorporação nos hábitos lisboetas, como em geral europeus, da degustação das novas bebidas quentes, como o chá, o café e o chocolate.

\section{BIBLIOGRAFIA}

ANTUNES, Mary Espírito Santo, coord. (200o) - Porcelanas da China: Colecção Ricardo do Espírito Santo Silva. Lisboa: Fundação Ricardo Espírito Santo Silva.

AVERY, George (1997) - Pots as packaging: The Spanish Olive Jar and Andalusian Transatlantic Commercial Activity, 16th-18th Centuries. A dissertation presented to the Graduate School of the University of Florida. Gainesville: University of Florida.

BERCERO, Julia Beltrán de Heredia; ALAIX, Núria Miró I (2010) - "El comerç de cerâmica a Barcelona als segles XVI-XVII: Itàlia, França, Portugal, els tallers del rin i xina”. In QUARHIS, Época II, Num. 6. Barcelona, pp. 14-91.

CASIMIRO, Tânia (2013) - "Faiança portuguesa: datação e evolução crono-estilística”. In Revista Portuguesa de Arqueologia, Vol. 16. Lisboa: Direcção-Geral do Património Cultural, pp. 351-367.

CHARNOCA, Cristina; MIGUEL, Lúcia; PINTO, Marina (2005) - Mercado da Ribeira: Relatório Final dos Trabalhos Arqueológicos. Lisboa: ERA - Arqueologia, S.A.

CRAIG, Jennifer (2013)- "Southeast Asian and Chinese Ceramics in the Shipwreck Galleries: the Abbott Collection Catalogue". In Report - Department of Maritime Archaeology, No. 302. WA: Museum, pp. 1-31.

ERNST, Marlieke (2011) - Talking sherds: Spanish ceramics in Caribbean context. Bachelor thesis: Faculty of Archeology. Leiden: Leiden University.

FERREIRA, Sara (2015) - O sítio do forte de São Paulo: estudo arqueológico da Ribeira Ocidental de Lisboa na época moderna. Dissertação de Mestrado em Arqueologia. Lisboa: Faculdade de Ciências Sociais e Humanas (U.N.L.).

FOX, Georgia Lynne (1998) - The study and analysis of the Kaolin clay tobacco pipe collection from seventeenth-century archeological site of Port Royal, Jamaica. Major Subject Anthropology. Texas: A\&M University.

GOGGIN, John M (1960). - The Spanish Olive Jar: an Introductory Study. New Have: Yale University Publications in Anthropology.

GOMES, Rosa Varela; GOMES, Mário Varela (1993) - “Cerâmicas vidradas e esmaltadas dos seculos XIV, XV e XVI, 
do Poço-cisterna de Silves". In Xelb:Revista de Arqueologia, Arte, Etnologia e Historia, № 3. Silves: Câmara Municipal de Silves, pp. 143-205.

HINTON, Jack (2012) - The Art of German Stoneware 1300 -1900: from the Charles W. Nichols collection and Philadelphia Museum of Art. Philadelphia Museum of Art: Yale University Press.

HUME, Ivor Noël (1970) - A guide to artifacts of colonial America. New York: Alfred A. Knopf.

MATOS, Maria Antónia Pinto de (1996) - A casa das porcelanas: cerâmica chinesa da casa-museu Dr. Anastácio Gonçalves. Lisboa: Instituto Português de Museus; London: Philip Wilson.

MEDICI, Teresa (2011) - “O espólio vítreo do Núcleo Arqueológico da Rua dos Correeiros, Lisboa”. In Revista Portuguesa de Arqueologia, Vol. 14. Lisboa: Direcção-Geral do Património Cultural, pp. 313-353.

OLIVEIRA, F. S., BROCHADO, S. V. (2017) - "Produções cerâmicas manuais do período Moderno, um contributo para o seu estudo". In Coelho, I., Torres, J., Gil, L., and Ramos, T. (eds.), Entre Ciência e Cultura: Da Interdisciplinaridade à Transversalidade da Arqueologia. Actas das VIII Jornadas de Jovens em Investigação Arqueológica. Lisboa: CHAM, pp. 251-26o.
ORTON, C. (1980) - Mathematics in Archeology. Cambridge: Cambridge University Press.

ORTON, C., TYERS, P., VINCE, A., (1993) - Pottery in Archaeology. Cambridge: University Press.

PINTO, Marina; FILIPE, Iola; MIGUEL, Lúcia (2011) - “Cachimbos de caulinos provenientes do Mercado da Ribeira: contributo para a História sócio-económica da Lisboa Moderna”. In Apontamentos de Arqueologia e Património, № 7. Lisboa: Núcleo de Investigação Arqueológica, ERA-Arqueologia, S.A., pp. 41-47.

PLEGUEZUELO, Alfonso (200o) - “Cerámicas para agua en el Barroco Español: una primera aproximación desde la literatura y la pintura. In Ars Longa: cuadernos de arte, nㅜ 9-10. Madrid, pp. 123-138.

SKERRY, E. Janine; HOOD, Suzunne Finle (2009) - SaltGlazed Stoneware in Early America. Williamsburg: Colonial Williamsburg.

VALENSTEIN, Suzanne G. (1989) - A Hand Book ofChinese Ceramics. New York: The Metropolitan Museum of Art.

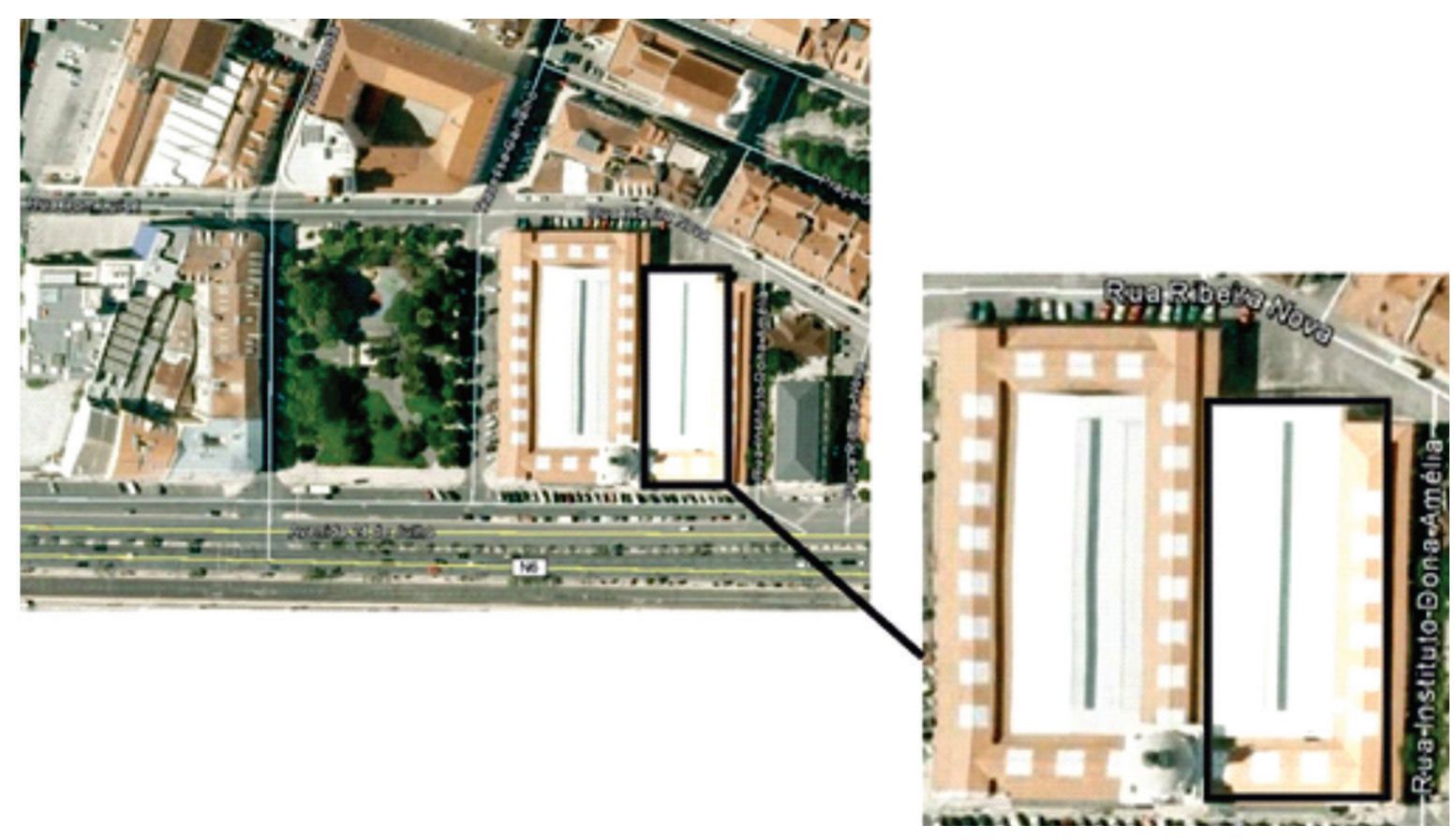

Figura 1 - Localização e pormenor da intervenção arqueológica. (Fonte: Google Earth,Dezembro de 2014, adaptado). 


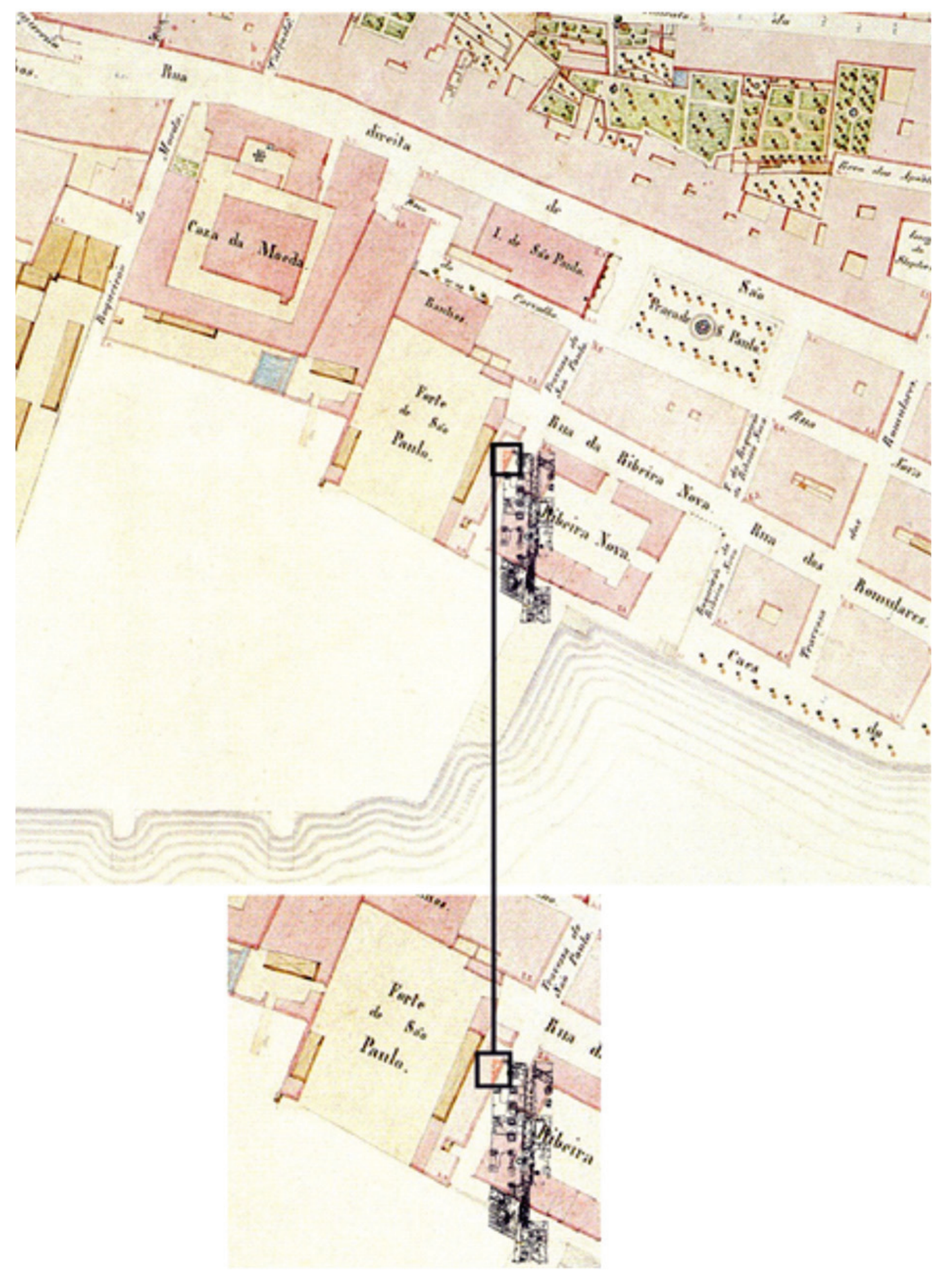

Figura 2 - Sobreposição do registo gráfico da intervenção ao levantamento topográfico de Filipe Folque de 1856. Em pormenor destaca-se o vestígio do lance Este do forte de São Paulo (Fontes: ERA-Arqueologia S.A. e Museu da Cidade de Lisboa, MC.GRA.48o, adaptado). 


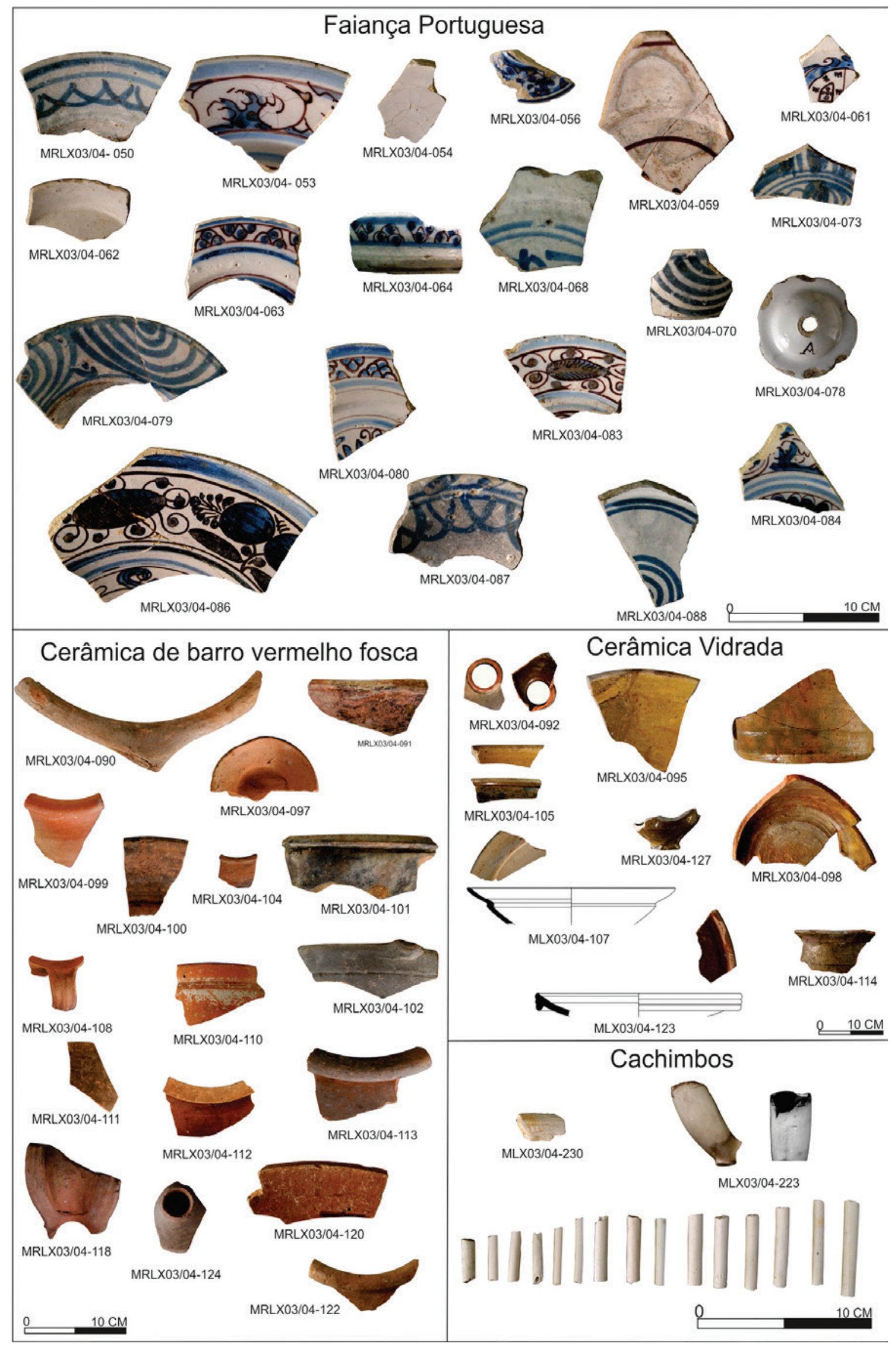

Figura 3 - Registo gráfico de alguns dos exemplares recolhidos em faiança portuguesa; cerâmica de barro vermelho fosca; cerâmica vidrada e cachimbos cerâmicos. 


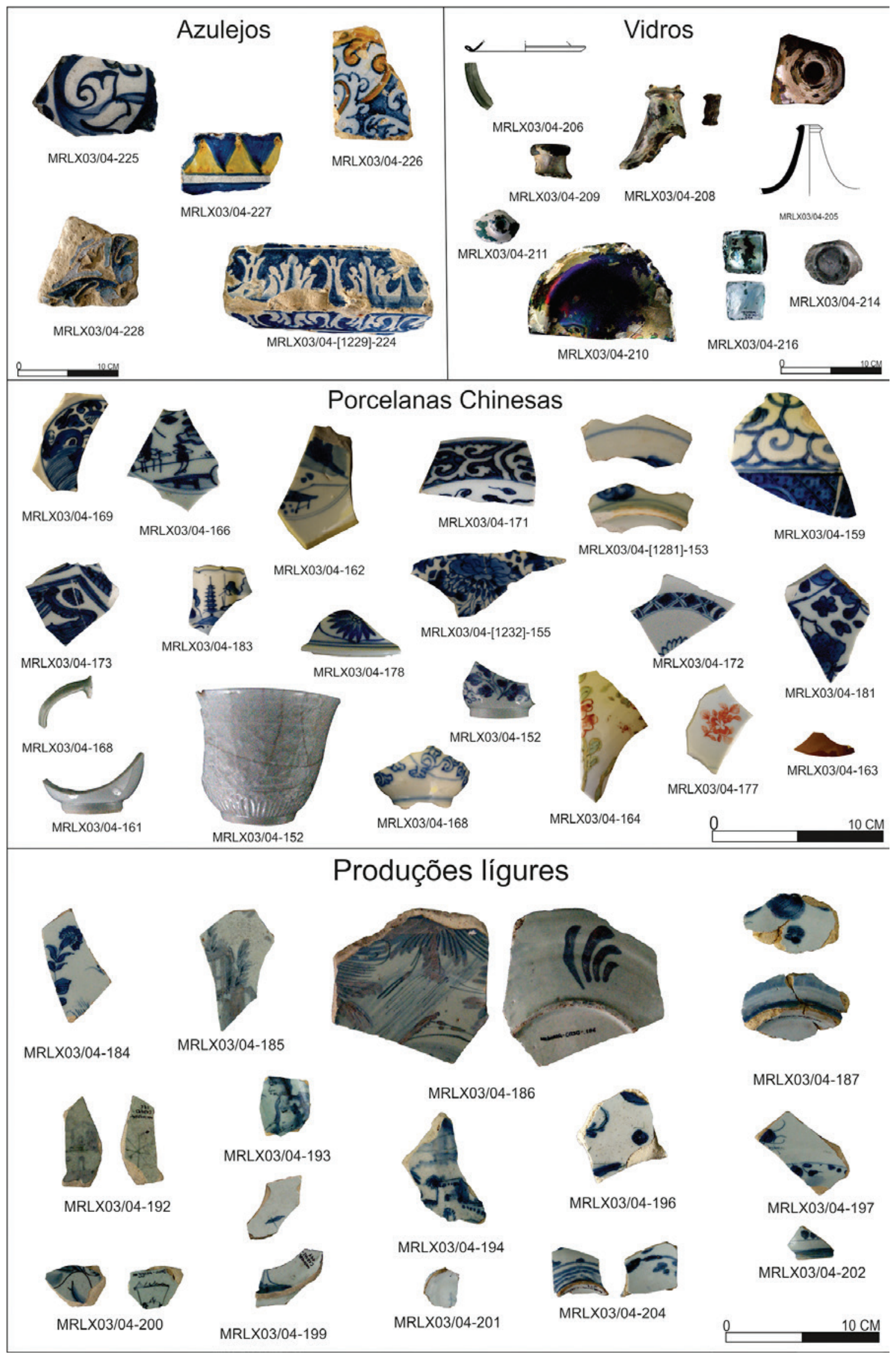

Figura 4 - Registo gráfico de alguns dos exemplares recolhidos de azulejos; em vidro; porcelanas chinesas e produções lígures. 


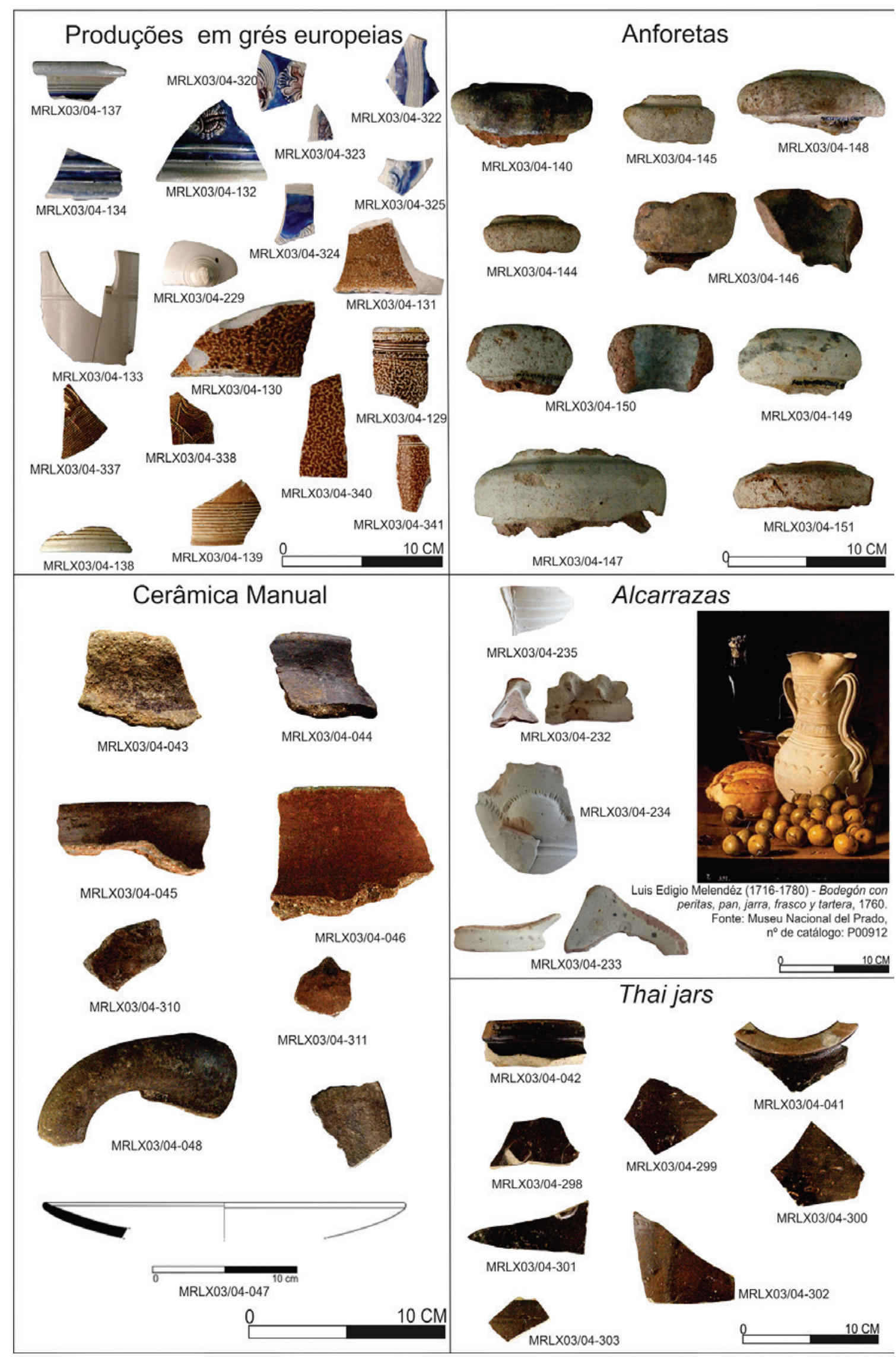

Figura 5-Registo gráfico de alguns dos exemplares recolhidos de produções em grés europeias; anforetas; cerâmica manual; alcarrazas e thai jars. 


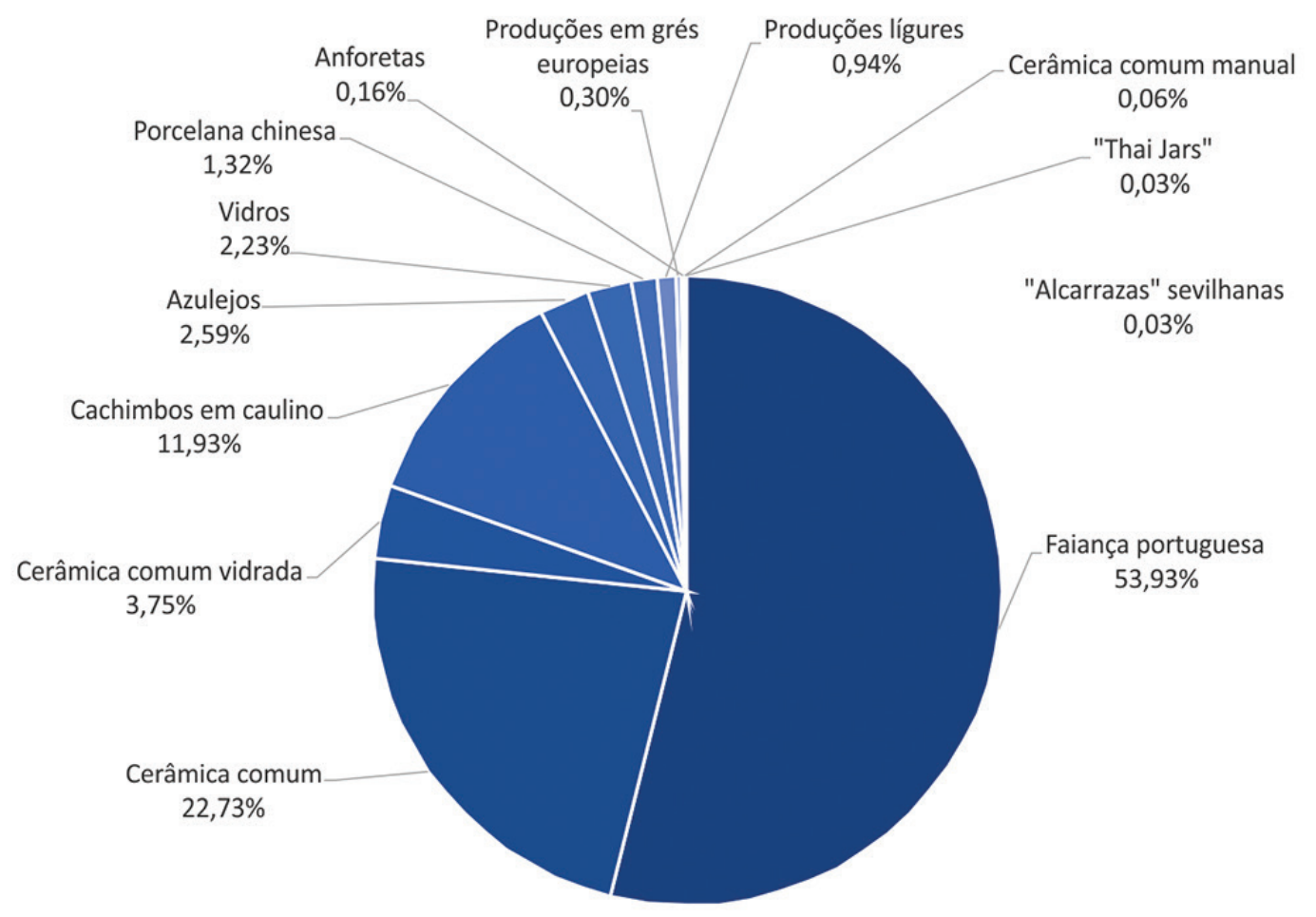

Gráfico 1 - Frequência percentual, por NMI, dos diferentes grupos de frabrico analisados, recolhidos nos depósitos de aterro do Sector 1 .

\begin{tabular}{|c|l|l|l|l|l|l|l|l|l|}
\hline Classe/Quartel & 1550 & 1575 & 1600 & 1625 & 1650 & 1675 & 1700 & 1725 & 1750 \\
\hline Faianças Portuguesas & & & & & & & & & \\
\hline C. barro vermelho fosco & & & & & & & & & \\
\hline C. Vidrada & & & & & & & & & \\
\hline Cachimbos em caulino & & & & & & & & & \\
\hline Azulejos & & & & & & & & & \\
\hline Vidros & & & & & & & & & \\
\hline Porcelanas Chinesas & & & & & & & & & \\
\hline Produções Lígures & & & & & & & & & \\
\hline Grés Europeus & & & & & & & & & \\
\hline Anforetas & & & & & & & & & \\
\hline Cerâmicas Manuais & & & & & & & & & \\
\hline Alcarrazas Sevilhanas & & & & & & & & & \\
\hline Thai Jars & & & & & & & & & \\
\hline
\end{tabular}

Tabela 1 - Confrontação da frequência cronológica no registo dos diferentes grupos de fabrico analisados, destaca-se a negro, a incidência cronológica das produções no primeiro quartel do século XVIII. 


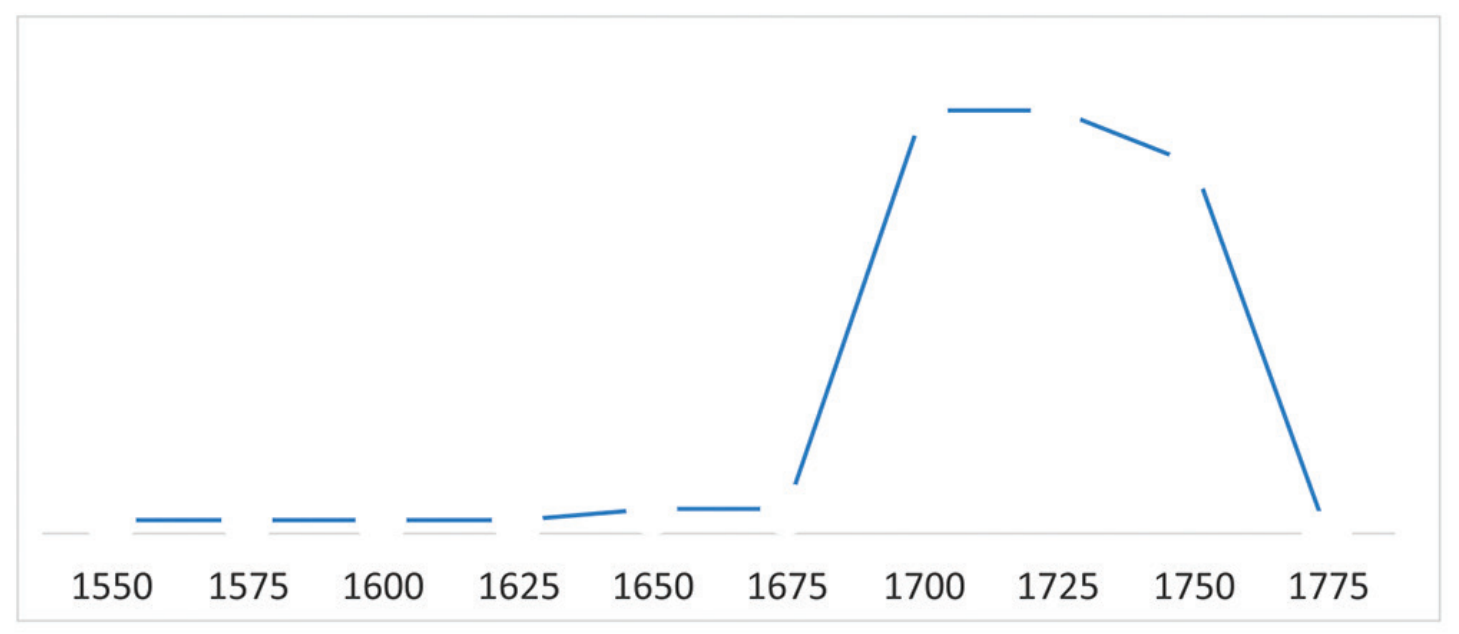

Gráfico 2 - Dispersão e frequência cronológica dos diferentes grupos de frabrico analisados, em NMI, recolhidos nos depósitos de aterro do Sector 1 (quartel). 



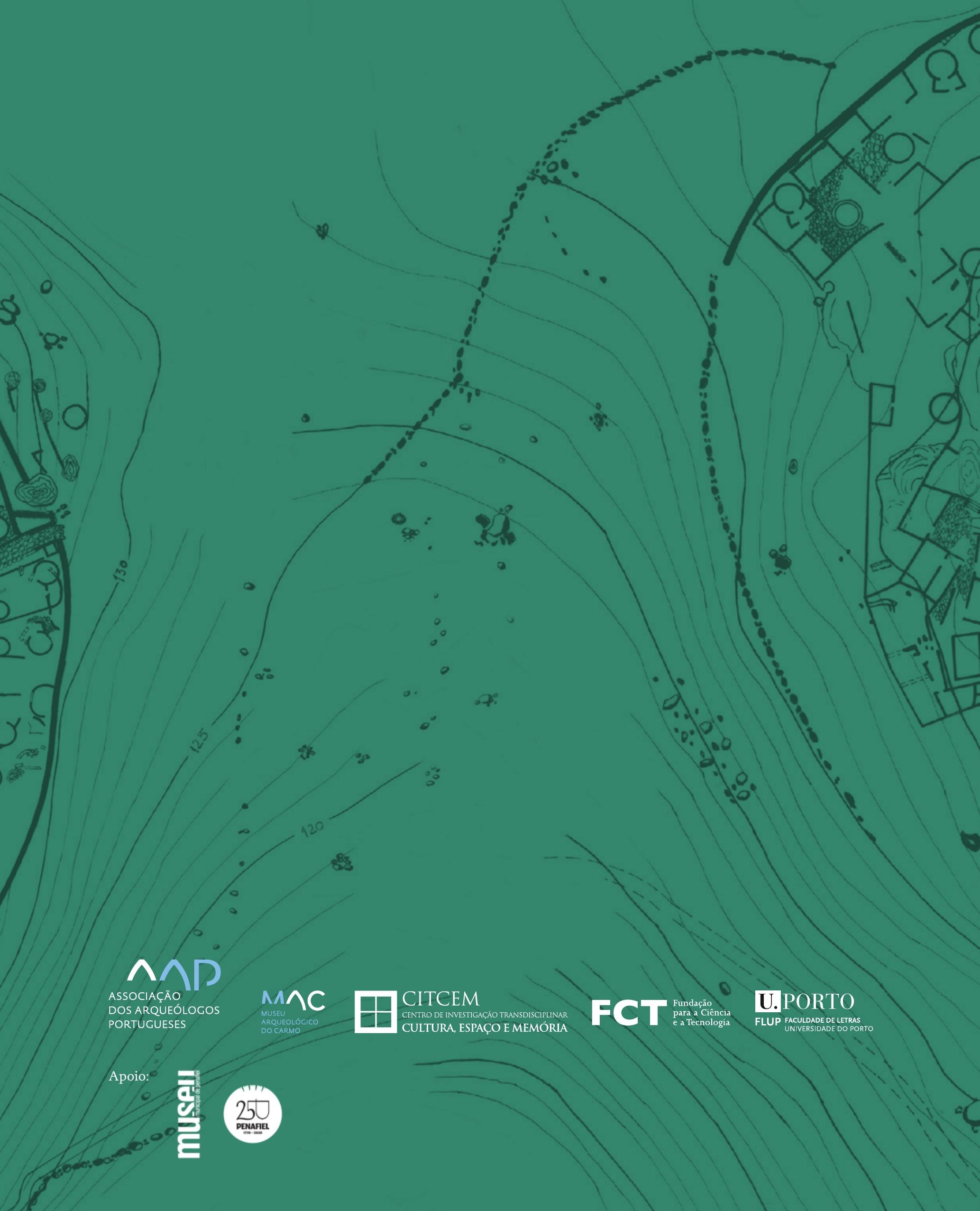

